\title{
Implication of Mining to Health in Maiganga Coal Mine, Gombe State, Nigeria \\ Amosu C.O.
}

\begin{abstract}
Operations of mining are large industrial scale in nature, with significant environmental impacts. The mining industry generates and produces wastes containing high concentrations of metals and metalloids which are highly toxic and destructive to the immediate landscape and environment. In addition, the continued use of the traditional methods of mining intensifies the emission of toxic and products that are not friendly to the ecosystem.. Even regulated and controlled mining sites release toxins into the surrounding environment. While mining has prospects and benefits to the economy, both in terms of its own economic impact and the value to other industries of its product, it almost always has adverse environmental impacts and eventually health impacts. There are numerous ways in which mines impact the health of nearby environments and local communities. Mining involves some generally standard processes and practices. This paper considers the effects and harm done to living things around the mine location. By understanding mining's threats to health and long-term well-being and by taking precautions to reduce harm in all mines, miners and other people in mining communities can better protect their health and improve their lives. This research will address questions like: which are the toxic substances causing health problems in Maiganga Coal Mine? What is the challenging impact of toxic substances in Maiganga coal Mine?

Keywords: Maiganga, Health, Mining, Toxic, Consequence,
\end{abstract} Reclamation

\section{INTRODUCTION}

$\mathrm{M}$ ines have some positive impact, such as employment opportunity and infrastructural development but their impact on health is negative, which can occur through both environmental and occupational health channels. The people closure to the mine is associated with higher incidence of waterborne diseases, typhoid and fever most likely associated with changes in water quality and distribution, whereas employment in the mines is clearly associated with acute respiratory infections as might be expected from working in dusty conditions with no protection (Priyambada P. and Dr. Sudhakar P., 2014). In North America, for example, the mining industry employs an estimated one million people and the industry in 1998 was estimated to be worth way more than $\$ 70$ billion. In countries such as Peru and South Africa, mining activities contribute more than $11 \%$ and $27.4 \%$ of GDP respectively.

Manuscript received on 30 March 2021 | Revised Manuscript received on 03 April 2021 | Manuscript Accepted on 15 October 2021 | Manuscript published on 30 October 2021. * Correspondence Author

Engr. Amosu C.O*., Department of Mineral and Petroleum Engineering Yaba College of Technology, Yaba. cyril.amosu@yabatech.edu.ng

(c) The Authors. Published by Lattice Science Publication (LSP). This is an open access article under the CC-BY-NC-ND license (http://creativecommons.org/licenses/by-nc-nd/4.0/)
Nonetheless, the mining sector has a lot of negative health and environmental impacts and sometimes the health cost of the mining activities can outweigh its benefits. Mining uses large amounts of energy requiring the transport and the combustion of high volumes of fossil fuels. Mining operations consume 7-10 percent of the world's energy production annually. Burning fossil fuels releases toxic substances such as mercury and polycyclic aromatic hydrocarbons (PAHs) into the atmosphere. Because of the remote nature of mining sites, the burning of fossil fuels typically takes place on site. In addition to significant energy needs, most mining requires massive amounts of water. Mining operations are also noisy and noise produced by human activities reduces the populations of animals nearby. Animals ranging from birds to deer are known to avoid areas with significant amounts of noise produced by people. The noise associated with mining operations could potentially have an adverse impact on subsistence hunting, making it more difficult for communities that rely on a subsistence diet to ensure livelihood. The EPA determined that noisy activity at the mine and transport road contributed to a decrease in farm harvest. According to Ademu, Obaje, Mohammed and Kumo (2020), there is no significant variation in ambient air quality parameters in the different locations worked on and the standards recommended by Federal Ministry of Environment. However, the values of particulate matter PM10 (coarse) at the coalmine and also at the Maiganga community, $359.00 \mu \mathrm{g} / \mathrm{m} 3$, and $358.00 \mu \mathrm{g} / \mathrm{m} 3$ respectively are higher than the value of $250 \mu \mathrm{g} / \mathrm{m} 3$ set as safety limit by Federal Ministry of Environment which suggests pollution.

\section{HEALTH EFFECT OF SOME MINERALS}

\section{A. TOXIC METALS AND ITS HEALTH CONSEQUENCES}

Mining activities releases toxic substances from the earth. Ore deposits are often associated with arsenic, lead, mercury and other toxic metals. These toxic metals often find their way into the air, water and food chains once they are released from underground rock formations during mining.

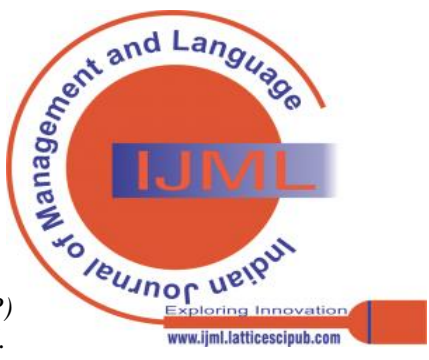


Implication of Mining to Health in Maiganga Coal Mine, Gombe State, Nigeria

Table 1: Some Toxic Metals Caused By Mining and their Health Consequences

\begin{tabular}{|c|c|c|}
\hline S/NO. & TOXIC METALS & HEALTH CONSEQUENCES \\
\hline 1 & Mercury & $\begin{array}{l}\text { It affects the central and peripheral nervous systems and causes } \\
\text { personality changes, deafness, changes in vision, loss of muscle } \\
\text { coordination or tremors, loss of sensation, and difficulties with memory. }\end{array}$ \\
\hline 2 & Arsenic & $\begin{array}{l}\text { It causes cancer of the skin, liver, bladder and lungs; as well as birth } \\
\text { defects and still births. }\end{array}$ \\
\hline 3 & Lead & $\begin{array}{l}\text { It destroys brain and nerve cells. It causes abnormal/reduced } \\
\text { physical/mental growth and lower intelligence, as well as deficit } \\
\text { hyperactivity disorder and antisocial behaviour. }\end{array}$ \\
\hline 4 & Antimony & $\begin{array}{l}\text { It causes pneumoconiosis (lung damage), lung cancer, alterations in } \\
\text { pulmonary function, chronic bronchitis, chronic emphysema, pleural } \\
\text { adhesions, increased blood pressure, altered EKG readings and heart } \\
\text { muscle damage. }\end{array}$ \\
\hline 5 & Cadmium & $\begin{array}{l}\text { It causes kidney, lung, and intestinal damage, as well as abnormal foetal } \\
\text { metabolism, low foetal weight and skeletal deformations, low birth } \\
\text { weight and reduced sperm count }\end{array}$ \\
\hline 6 & Cyanide & $\begin{array}{l}\text { It causes breathing difficulties, chest pain, vomiting, blood changes, } \\
\text { headaches, and enlargement of the thyroid gland and leads to coma and } \\
\text { death. }\end{array}$ \\
\hline
\end{tabular}

Table 2: Effects of Mining on The Environment

\begin{tabular}{|l|l|l|}
\hline S/No. & & EFFECTS OF MINING ON THE ENVIRONMENT \\
\hline 1 & Water Resources & $\begin{array}{l}\text { It affects drinking water and pollutes surface and groundwater, especially } \\
\text { in rural areas dependent on ground water wells or potable surface waters. }\end{array}$ \\
\hline 2 & Society and Traditional Culture & $\begin{array}{l}\text { B. It contaminates traditional food sources, its food gathering and } \\
\text { local plants with heavy metals toxins (Causes and Effects of Mining on } \\
\text { Human Health and the Environment. 2012). }\end{array}$ \\
\hline 3 & Agriculture & $\begin{array}{l}\text { Tailing dams and mine dumps become eroded and render farming } \\
\text { or grazing land unproductive }\end{array}$ \\
\hline 5 & Aquatic Animals & $\begin{array}{l}\text { It deteriorate farming activities and causes animals to lose their habitats } \\
\text { that the aquatic animals feed on. }\end{array}$ \\
\hline 6 & Vegetation Cover & $\begin{array}{l}\text { It causes deforestation, clogging of the leaf surfaces of plants by metallic- } \\
\text { laden dust particles which modify their pH, hereby causing unavailability } \\
\text { of nutrients. }\end{array}$ \\
\hline
\end{tabular}




\section{LITERATURE REVIEW}

Maiganga Coal may be dull, dark brown to black, and soft and crumbly at the lower end of the range, to bright, black, hard, and relatively strong at the upper end (Onoduku, 2014).

Activated carbon is an amorphous form of carbon that has been specially treated to acquire

improved adsorptive properties such as surface area, pore volume, pore size and pore size

distribution (Umar et al, 2020). Maiganga coalfield which is currently receiving considerable attention from coal stakeholders has deposit which is also a prime target for power generation by the Nigerian government (Matthew et al, 2017).Resettlement takes place when major development projects, which are important elements of development, force people who have lived in a region for a long time to leave their homes, and their place in society, economic and agricultural activities, relationships and opportunities and any other immovable properties, to live in other places (Dogan et al, 1991). The problems caused by mining activities are land degradation, disposal of over burden, deforestation, washing rejects, subsidence, water pollution due to wash off, discharge of mine water, acid mine drainage, coal washing operation, air pollution due to release of gases and dust, noise pollution, mine fires, damage to forest flora and fauna, wildlife habitat destruction and occupational health hazards (Singh et. al,. 2011). By developing clean coal technologies, Nigeria will be able to use her considerable coal resources better and reduce the emissions of harmful substances associated with coal mining, thereby make a significant contribution to Nigeria's energy needs (Denloye and Akinola, 2017). Both the mineworkers and the Maiganga people that live in the area are daily exposed to hazardous materials with the resultant health and environmental risks and effects which are pneumoconiosis, silicosis, Acid Mine Drainage (AMD), water pollution, high ash and moisture contents (Chibuisi,2017). With the exception of Ni in Maiganga Coal Mine and farmland areas which exceeded the permissible limit value $15 \mathrm{mg} / \mathrm{kg}$, the other heavy metals levels were within permissible limit set by WHO in 2007 (Babayo, Santuraki and Adebayo, 2018). Air pollution is the introduction of chemicals, particulate matter, or biological materials that cause harm or discomfort to humans or other living organisms, or cause damage to the natural environment or built environment, into the atmosphere (Tawari and Abowei, 2012). Mining of solid minerals from the earth's surface is another means in which air gets polluted through land site clearing, drilling, blasting, hauling, collection, and transportation (Abaje, Bello and Ahmad, 2020). The proven reserves of coal so far in the country are 639 million tonnes while the inferred reserves are about 2.75 billion tonnes,consisting approximately of 49\% subbituminous, 39\% bituminous, and 12\% lignitic coals (The Presidency, 2003). According to the WHO's suggestion, the health risk of ${ }^{226} \mathrm{Ra}$ in drinking water is mainly concerned with the effective dose less than chemical radio-toxicity (World Health Organization,2004).

\section{MATERIAL AND METHODS}

\section{SCOPE OF THIS STUDY}

This study targets the toxicity of some substances and their causes in Maiganga Coal Mine. It sought to establish and propose reclamation as best possible option using literature reviews of metallic particles in mining most like found in Maiganga Coal Mine.

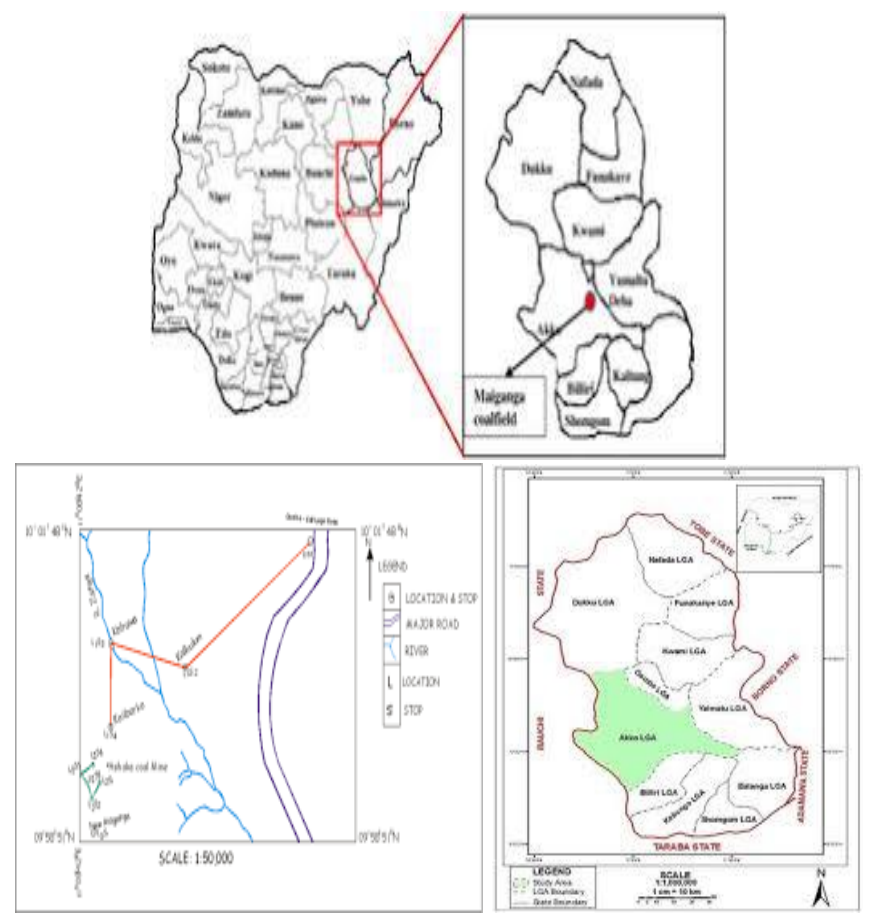

Figure 1: Locational Map of Maiganga Coal Mine (Source: Matthew et al, 2016, Chibuisi, 2017 and Oruonye, Iliya and Ahmed, 2016) - journals.plos.org and pubs.sciepub.com

\section{GEOLOGY OF MAIGANGA COAL MINE}

Maiganga is a community located between Latitude $10^{\circ}$ $02^{\prime}$ to $10^{\circ} 05^{\circ}$ and Longitude $11^{\circ} 06^{\prime}$ to $11^{\circ} 08^{\prime}$ in Akko Local Government Area of Gombe state, North-East (Matthew et al, 2016).

It is situated at $8 \mathrm{~km}$ off Gombe-Yola road immeeediately after Kumo town (Onoduku, 2014). The study area, Maiganga community covers an area of about 20,129.47 Acres (48.16

$\mathrm{Km}^{2}$ ) (Oruonye et al., 2016). Rainfall ranges between 850 to $1000 \mathrm{~mm} 3$ and the rainy season last between 5 to 6 months. Temperature is relatively high for most part of the year. Geologically the study area is developed on basement complex rocks. The vegetation consists of sparse trees, scrubs and open grasses. Some of the tree species in the area include butyrospermum, Mumparadoxum. Tamanrindus indica, Pakia biglobosa, Balanite aegyptiaca, Afzelia Africana, fabia, albida.

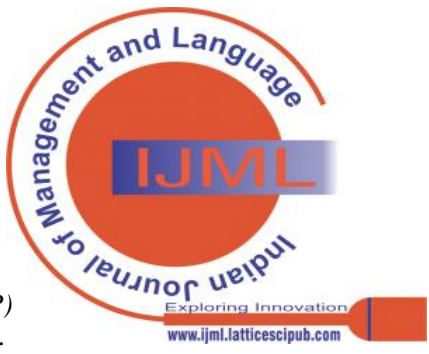


The population of the study area consists of ethnic groups such as Jukun, Fulani and Tangale the dominant group among others. The population of Maiganga village based on the 2006 population census is about 3,520 people. The economic activity of the study area is farming which includes the cultivation of different crops such as maize, millet, guinea corn, groundnut, sorghum and groundnut (Abdulsalam M., Oruonye, E.D., Ahmed Y.M. and Mbaya L., 2016). The maiganga coal is hosted within the Maastrichtian Gombe formation located at the Northern Benue Trough of North-East Nigeria. It is a low-rank subbituminous coal (Matthew etal, 2016).It lies within the Gombe sandstone, adjacent to and above the Pidiga formation (Obaje, 2009). It was laid down in non-marine possibly delta plane condition of upper continental sequenceof estuarine and deltaic sandstones, siltstone and iron stone which overlie the sediments of the Zambuk ridge and the Chad Basinin the western part of the region(Offodile, 1976). It was a mine owned by the management of Maiganga Coal Mining Company, but cultivated by individual; presently managed by Lafarge Africa Plc for tree planting. Maiganga Coal Mine has an estimated proven Coal reserve of 4.5 million tons at the site (Maina, Kachalla, and Comfort, 2016).

This study is helpful to reveal the causes of health challenges caused by mining and providing clues, especially reclamation and resettlement to sustain man and preserve his environment. Its significance is to address the health implication caused by metallic toxins in Maiganga Coal Mine. This will add its contribution to sustainable policymaking at the industry level. This work is however limited by resource constraints, proximity, time and insufficient information from the internet. Researchers chose to study implication of mining on health in Maiganga Coal as it impacts on man and his environment.
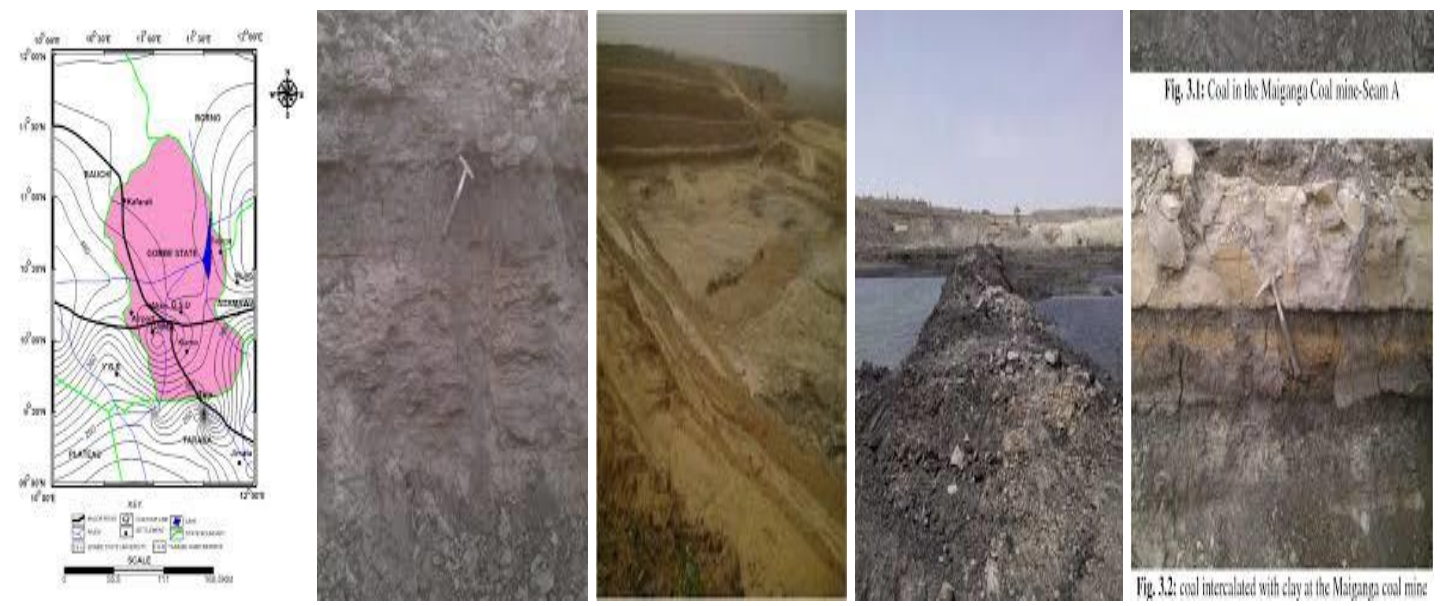

Figure 2: Gological Map of Maiganga Coal Mine (Source: pubs.sciepub.com, researchgate.net and semanticscholar.org)

\section{DRAINAGE SYSTEM IN MAIGANGA}
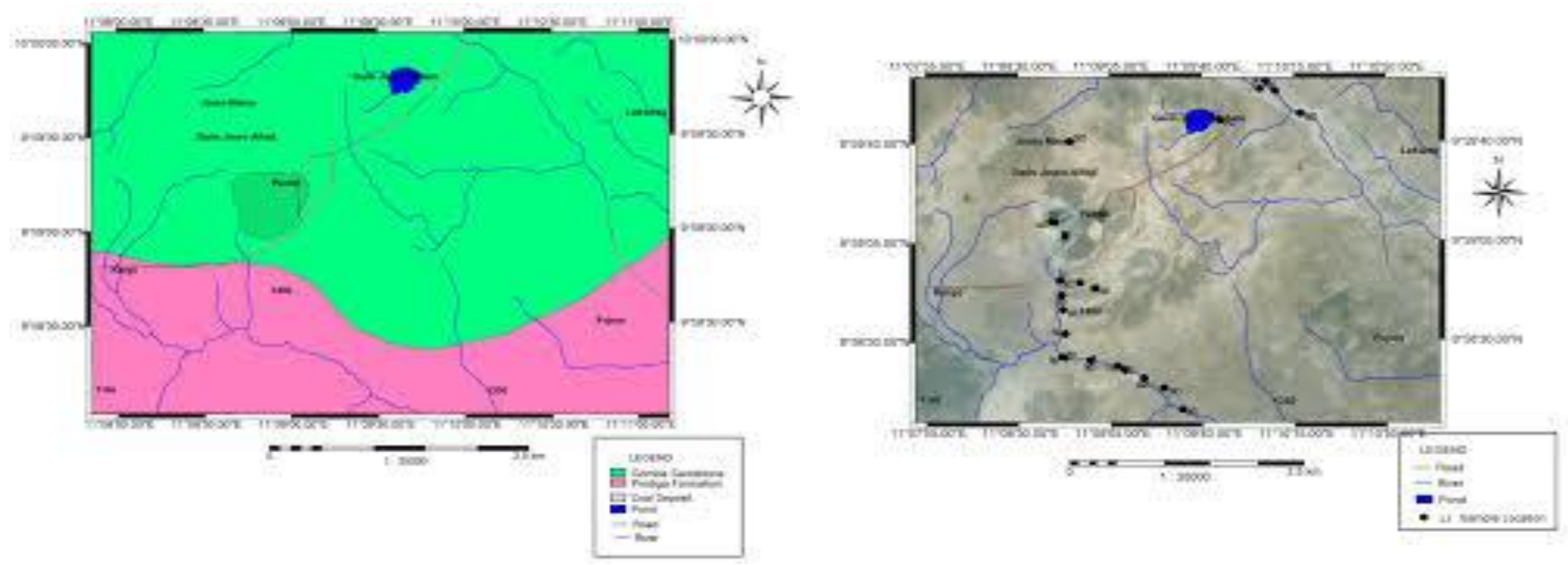

Fig. 3: Drainage in Maiganaga Coal Mine (Source: journals.indexcorpernicus.com)

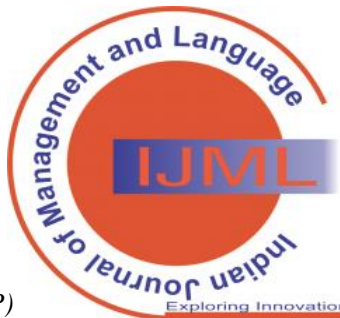




\section{DATA AND METHODOLOGY}

DATA REVIEW AND ANALYSIS

Table 3: Characteristics of Maiganga Coal Mine (Source: Nyakuma, 2015)

\begin{tabular}{|l|l|l|l|l|l|l|l|l|l|l|}
\hline Carbon & Hydrogen & Nitrogen & Sulphur & Oxygen & Ash & $\begin{array}{l}\text { Fixed } \\
\text { Carbon }\end{array}$ & $\begin{array}{l}\text { Volatile } \\
\text { Matter }\end{array}$ & $\begin{array}{l}\text { Mineral } \\
\text { Matter }\end{array}$ & Moisture & $\begin{array}{l}\text { Heating } \\
\text { Value }\end{array}$ \\
\hline $61.69 \%$ & $4.42 \%$ & $1.07 \%$ & $0.39 \%$ & $32.16 \%$ & $21.05 \%$ & $22.52 \%$ & $51.16 \%$ & $22.95 \%$ & $5.28 \%$ & $23.7 \mathrm{MJ} / \mathrm{Kg}$ \\
\hline & & & & & & & & & & \\
\hline
\end{tabular}

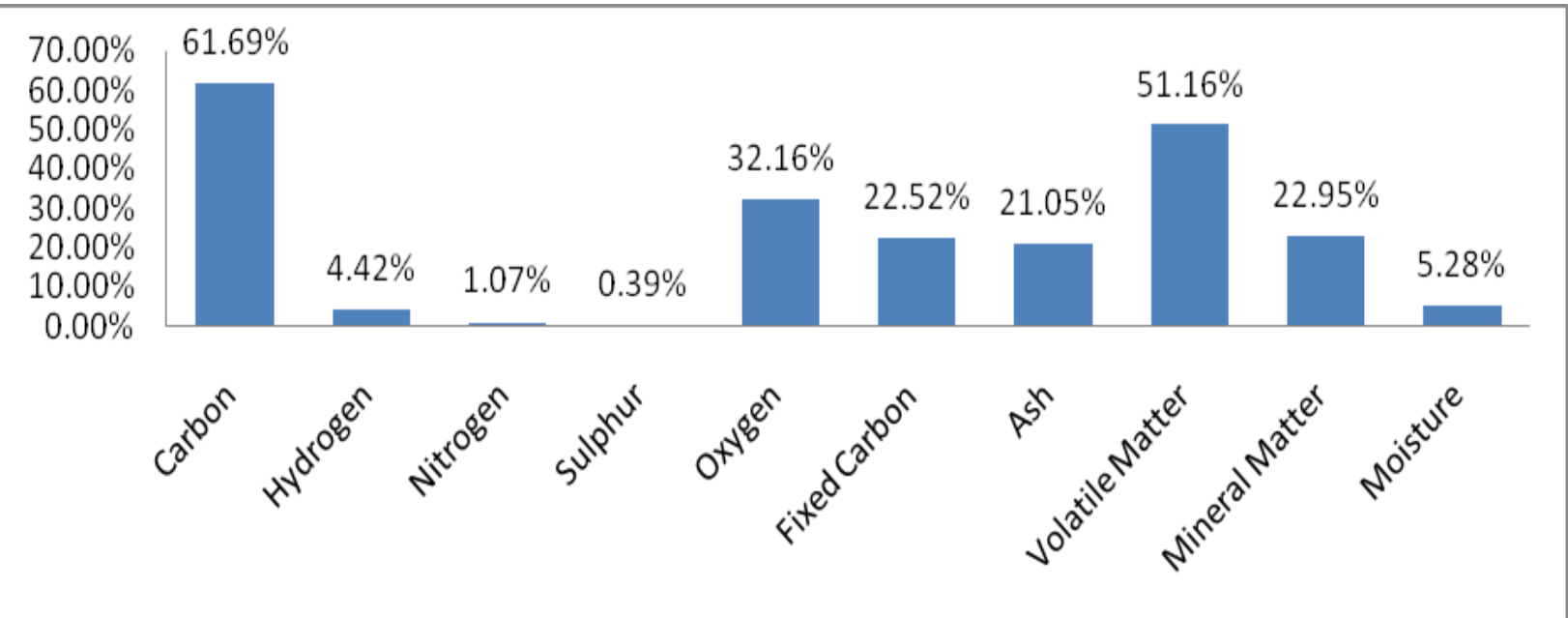

Figure 4: Bar Graph showing the property of Maiganga Coal Mine

On Maiganga, mean activity values of $11.90 \pm 3.0,17.72 \pm$

3.60 and $70.44 \pm 20.4 \mathrm{~Bq} / \mathrm{Kg}$ were obtained for Radon

$\left({ }^{226} \mathrm{Ra}\right)$, Thorium $\left({ }^{232} \mathrm{Th}\right)$ and Potassium $\left({ }^{40} \mathrm{~K}\right)$ respectively (Kolo, Amin, Khandaker and Abdullah, 2017).

Table 4: Representing radionuclide Metallic Concentration on Maiganga Coal Samples (Source: Kolo, Amin, Khandaker and Abdullah, 2017)

\begin{tabular}{|l|l|}
\hline \multicolumn{2}{|l|}{ Radionuclide Concentration } \\
\hline Radionuclide & Mean Value of Concentration $(\mathbf{B q} / \mathbf{K g})$ \\
\hline Radon $\left({ }^{226} \mathrm{Ra}\right)$ & $11.90 \pm 3.0$ \\
\hline Thorium $\left({ }^{232} \mathrm{Th}\right)$ & $17.72 \pm 3.60$ \\
\hline Potassium $\left({ }^{40} \mathrm{~K}\right)$ & $70.44 \pm 20.4$ \\
\hline
\end{tabular}

Table 5: Re-computing and re-organizing the radionuclide Concentration

\begin{tabular}{|l|l|l|}
\hline \multicolumn{2}{|l|}{ Radionuclide Concentration } & Mean Value of Concentration (Bq/Kg) \\
\hline Radionuclide & 14.9 & 8.9 \\
\hline Radon $\left({ }^{226} \mathrm{Ra}\right)$ & 21.32 & 50.04 \\
\hline Thorium $\left({ }^{232} \mathrm{Th}\right)$ & 90.84 & 50.04 \\
\hline Potassium $\left({ }^{40} \mathrm{~K}\right)$ & & \\
\hline
\end{tabular}




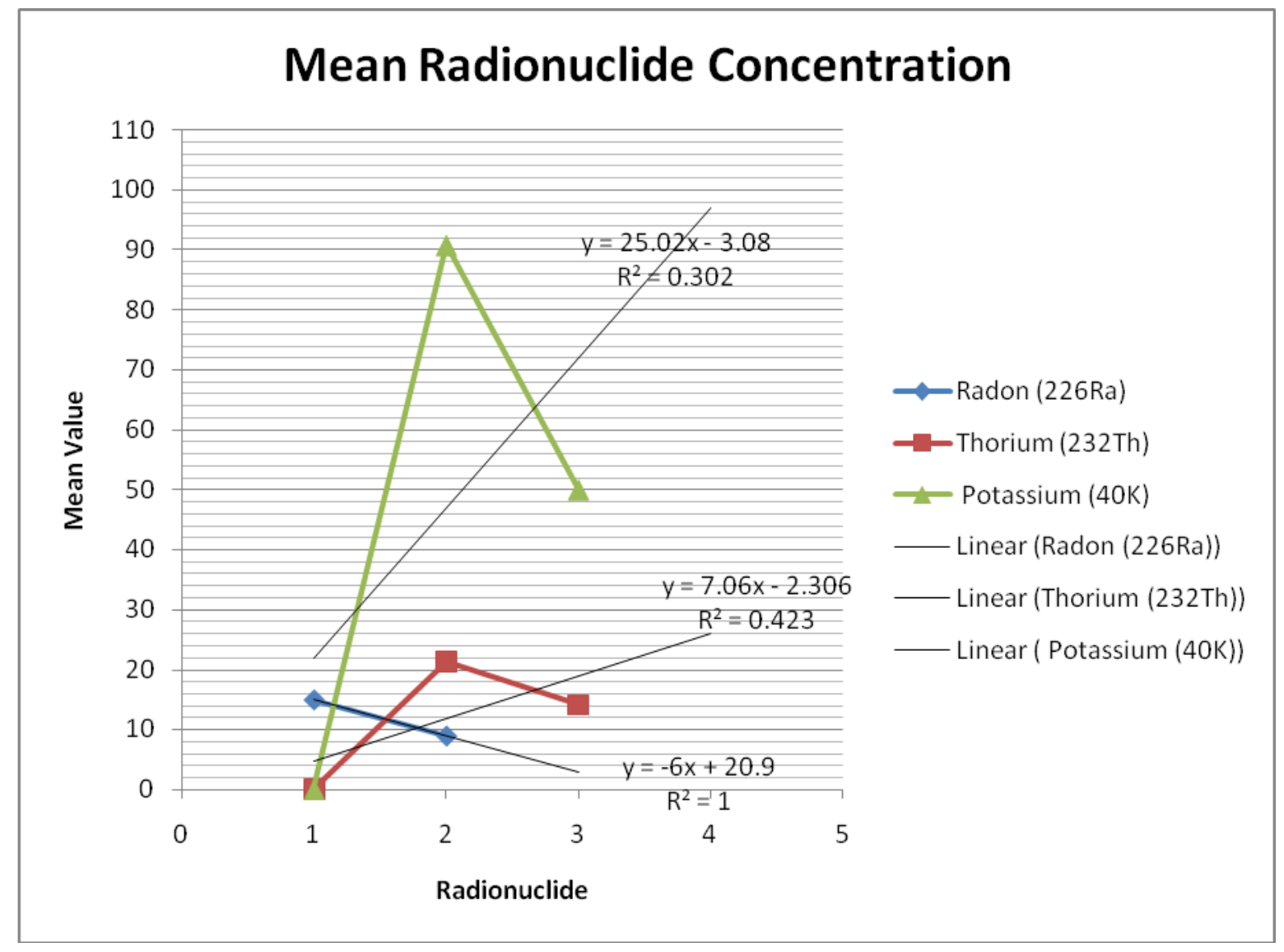

Figure 5: Graph from Re-computing and re-organizing the radionuclide Concentration

On Maiganga, Adamu, Mubarak, Mahmoud (2014) used Atomic Absorption Spectrophotometer (AAS) to read the heavy metals concentration in the water samples in borehole, hand dug well and the mine drain water around the coal mine area. This was juxtaposed with the expected standard of National Environmental Standards and Regulations Enforcement Agency - NESREA (2011).

Table 6: Adamu, Mubarak, Mahmoud (2014) comparison between Atomic Absorption Spectrophotometer (AAS) and Laboratory analysis (NESREA Standard 2011) of Maiganga Water Samples.

\begin{tabular}{|c|c|c|c|c|}
\hline \multirow[t]{2}{*}{ PARAMETERS/UNITS } & \multicolumn{3}{|c|}{ WATER SAMPLES } & \multirow{2}{*}{$\begin{array}{c}\text { NESREA } \\
\text { STANDARD }\end{array}$} \\
\hline & $\begin{array}{l}\text { MINE } \\
\text { DRAIN }\end{array}$ & BOREHOLE & $\begin{array}{c}\text { HAND } \\
\text { DUG } \\
\text { WELL }\end{array}$ & \\
\hline TEMPERATURE ${ }^{\circ} \mathrm{C}$ & 26.5 & 26.4 & 26.5 & - \\
\hline $\mathrm{pH}$ & 6.9 & 7 & 7.1 & $6.5-8.5$ \\
\hline COLOUR, P.t Co & 8 & 332 & 45 & 15 \\
\hline APPERANCE & Obj & Obj & Obj & Unobj \\
\hline TASTE & Unobj & Unobj & Unobj & Unobj \\
\hline ODOUR & Unobj & Unobj & Unobj & Unobj \\
\hline TURBIDITY, NTU & 23 & 33 & 12 & 5 \\
\hline $\begin{array}{l}\text { ELECTRICAL } \\
\text { CONDUCTIVITY, Us/cm }\end{array}$ & 434 & 155 & 300 & 1000 \\
\hline TOTAL DISSOLVE SOLIDS, mg/l & 217 & 76.9 & 149 & 500 \\
\hline T. HARDNESS, mg/l & 248 & 50 & 120 & 150 \\
\hline
\end{tabular}

(Source: NESREA Standard 2011 and laboratory analysis)

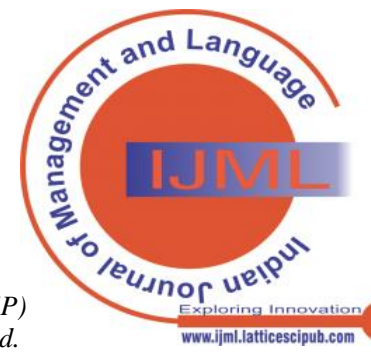


Table 7: Chemical Analysis of the Water in Maiganga

\begin{tabular}{|c|c|c|c|c|}
\hline \multirow{2}{*}{$\begin{array}{c}\text { PARAMETERS } \\
\text { (mg/l) }\end{array}$} & \multicolumn{3}{|c|}{ WATER SAMPLES } & \multirow{2}{*}{$\begin{array}{c}\text { NESREA } \\
\text { STANDARD }\end{array}$} \\
\hline & MINE DRAIN & BOREHOLE & HAND DUG WELL & \\
\hline Calcium & 143 & 32 & 74 & 70 \\
\hline Magnesium & 21.04 & 1.45 & 2.23 & 0.20 \\
\hline Iron & 4.30 & 12.02 & 1.4 & 0.03 \\
\hline Copper & 0.06 & 0.12 & 0.12 & 1.0 \\
\hline Fluoride & 0.21 & 1.42 & 1.02 & 1.0 \\
\hline Zinc & 0.54 & 0.50 & 0.52 & 421 \\
\hline Nitrate & 155 & 75 & 143 & 50 \\
\hline Nitrite & 1.02 & 1.43 & 1.05 & 0.02 \\
\hline Manganese & 0.00 & 1.24 & 0.00 & 0.05 \\
\hline Lead & 0.513 & 0.502 & 0.511 & 164 \\
\hline Sulphate & 50 & 20 & 36 & 100 \\
\hline Chloride & 9 & 14 & 21 & 250 \\
\hline Chromium & 0.00 & 5.33 & 0.00 & 0.05 \\
\hline Barium & 0.00 & 0.54 & 0.00 & 0.005 \\
\hline Cadmium & 0.45 & 0.299 & 0.011 & 3 \\
\hline Phosphate & 0.00 & 0.00 & 0.00 & 10 \\
\hline Cyanide & 0.032 & 0.73 & 0.004 & 0.001 \\
\hline
\end{tabular}

(Source: NESREA standard for drinking water quality, 2011 and laboratory analysis)
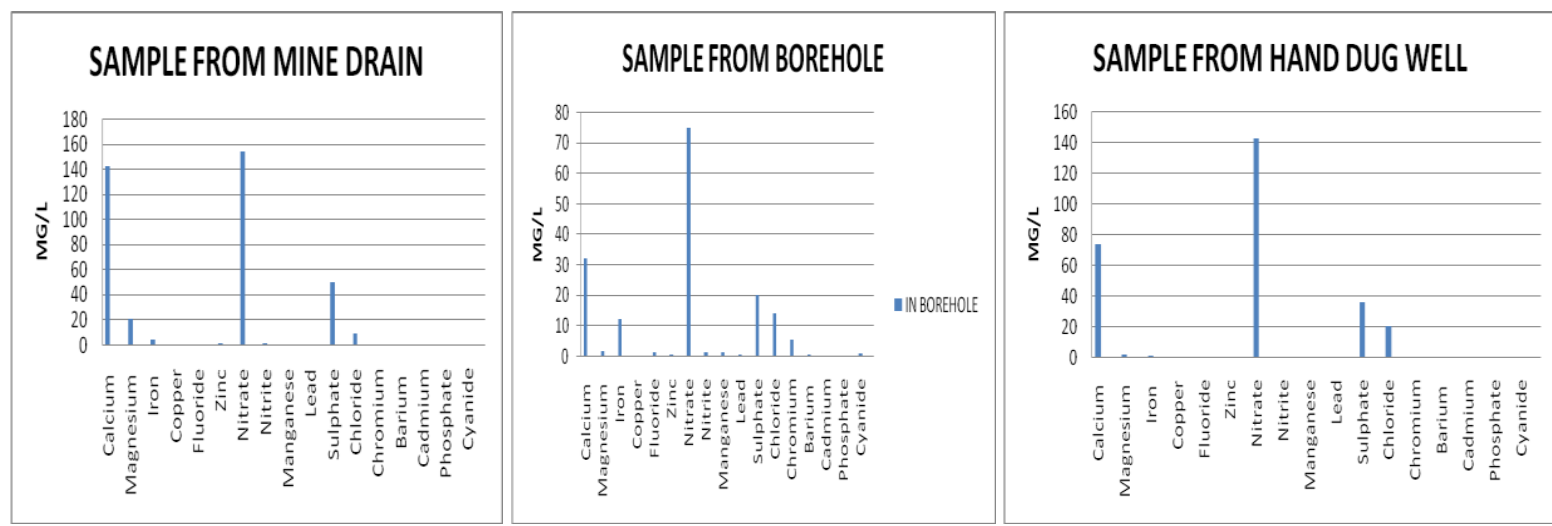

Figure 6: Graphs showing the chemical analysis of the samples from mine drain, borehole and dug well in Maiganaga

SOLUTIONS TO CHALLENGE CAUSED BY

The solution to the abandoned Maiganga Coal mine:

\section{A. RECLAMATION IN MAIGANGA}

\section{Reclamation:}

This is the recovery of bad or wasted land, and turning it into a useful or beneficial purpose, like residential, social, commercial and industrial.

\section{Importance of Reclamation}

- It increases land area

- It encourages agricultural and forestry activities MINING IN MAIGANGA COAL MINE

- It may be used for grazing by ruminant animals such as sheep, cattle, and goats.

- It enhances aesthetic value (Oruonye, Iliya and Ahmed, 2016).

Methods of Land Reclamation

- Re-vegetation: Is the planned process of planting several covers of vegetation over an abandoned mined area.

Published By: 
- Landscaping: These involve constructing drainages; effective sediment control system, doing tilling, ploughing and harrowing operations; covering/burying lying wastes of rocks, tailings.

- Soil amelioration: It involves treatment of surface soil with mulches and the application of gypsum to neutralize alkalinity or lime to neutralize soil acidity.

- Soil Replacement or backfilling: This involves returning packed or stockpiled top-soil that was initially removed and separated before mining commenced its operation to abandoned mined area.
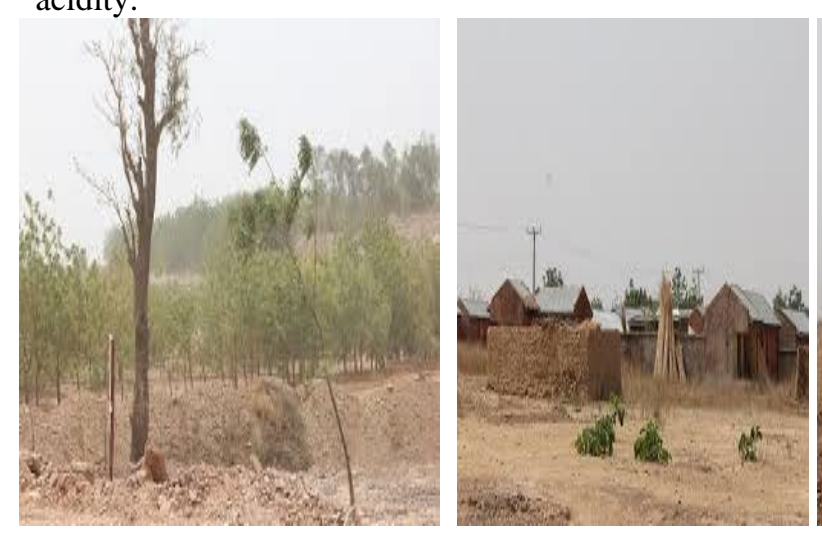

Figure 7: Reclamation in Maiganaga Coal Mine (Source: Oruonye, Iliya and Ahmed, 2016).
According to Oruonye, Iliya and Ahmed, (2016), findings show the following in table 8 .

Table 8: Proportion of land under mining and reclamation in the area

\begin{tabular}{|l|l|l|l|}
\hline S/No. & Status of land & $\begin{array}{l}\text { Total area } \\
\text { (hectares) }\end{array}$ & $\begin{array}{l}\text { Percentage } \\
(\mathbf{\% )}\end{array}$ \\
\hline 1 & $\begin{array}{l}\text { Land area under } \\
\text { mining }\end{array}$ & 78 & 13 \\
\hline 2 & $\begin{array}{l}\text { Total land area } \\
\text { for Mining }\end{array}$ & 474 & 79 \\
\hline 3 & $\begin{array}{l}\text { Total Land area } \\
\text { under reclamation }\end{array}$ & 48 & 8 \\
\hline 4 & Total & $\mathbf{6 0 0}$ & $\mathbf{1 0 0}$ \\
\hline
\end{tabular}

(Source: Oruonye, Iliya and Ahmed, 2016)

Table 9: Plant species identified in the Reclaimed area

\begin{tabular}{|l|l|l|l|}
\hline S/No & $\begin{array}{l}\text { Name of plant } \\
\text { species }\end{array}$ & $\begin{array}{l}\text { Number } \\
\text { planted }\end{array}$ & Percentages \\
\hline 1 & Azadirachta indica & 1000 & 16 \\
\hline 2 & $\begin{array}{l}\text { Anacardium } \\
\text { occidentale }\end{array}$ & 900 & 15 \\
\hline 3 & Acacia senegal & 700 & 12 \\
\hline 4 & $\begin{array}{l}\text { Eucalyptus } \\
\text { camaldulensis }\end{array}$ & 800 & 13 \\
\hline 5 & Jatropha curcas & 500 & 08 \\
\hline 6 & Mangifera indica & 1200 & 20 \\
\hline 7 & Tectona grandis & 1000 & 16 \\
\hline 8 & Total & $\mathbf{6 1 0 0}$ & $\mathbf{1 0 0}$ \\
\hline
\end{tabular}

(Source: Oruonye, Iliya and Ahmed, 2016)

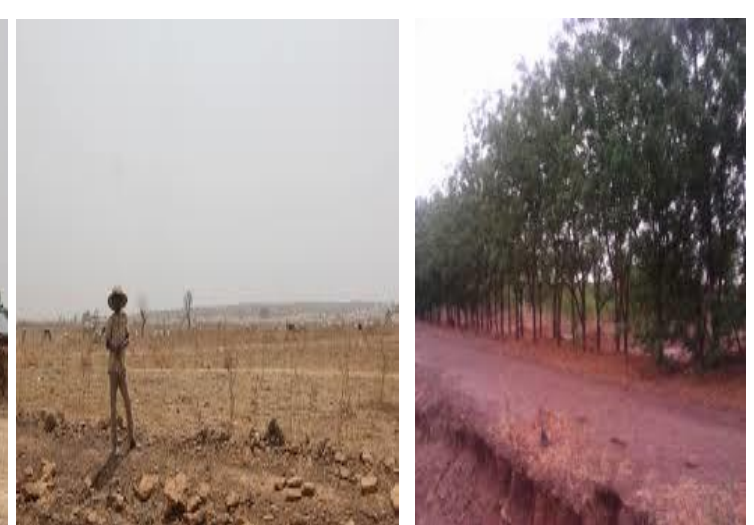

B. RESETTLEMENT SCHEME IN MAIGANGA AND ITS ENVIRONS

(Abdulsalam, Oruonye, Ahmed and Mbaya, 2016) in their paper examined the socio-economic impact of Maiganga resettlement scheme for consisting 976 persons in three (3) communities in Akko LGA of Gombe State as seen in table 10. Their data was collected through field observation, questionnaire, interviews and other secondary materials.

Table 10: Resettlement Scheme of Maiganga Communities

\begin{tabular}{|l|l|l|}
\hline S/No. & $\begin{array}{l}\text { RESETTLEMENT } \\
\text { VENTURE }\end{array}$ & QUANTITY \\
\hline 1 & Houses & 75 \\
\hline 2 & Boreholes & 4 \\
\hline 3 & $\begin{array}{l}\text { Primary school of three blocks } \\
\text { of classroom }\end{array}$ & 1 \\
\hline 4 & Skill acquisition centre & 1 \\
\hline 5 & Primary health & 1 \\
\hline 6 & Care/maternity & 3 \\
\hline 7 & transformer with electricity & 3 \\
\hline 8 & Mosques & 1 \\
\hline 9 & Church & 1 \\
\hline
\end{tabular}

(Source: Abdulsalam, Oruonye, Ahmed and Mbaya, 2016)

Monetary compensations were paid to the farmers for loss of farm lands. The compensation ranges between $\$ 10,000$ (USD 36) to $\$ 150,000$ (USD 536) depending on the size of farm land lost.

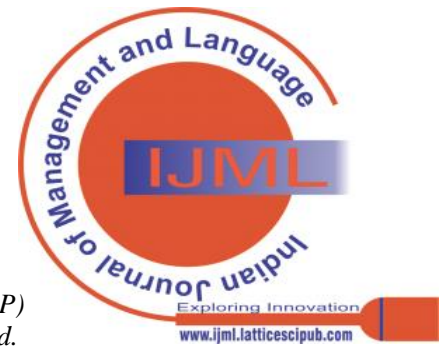




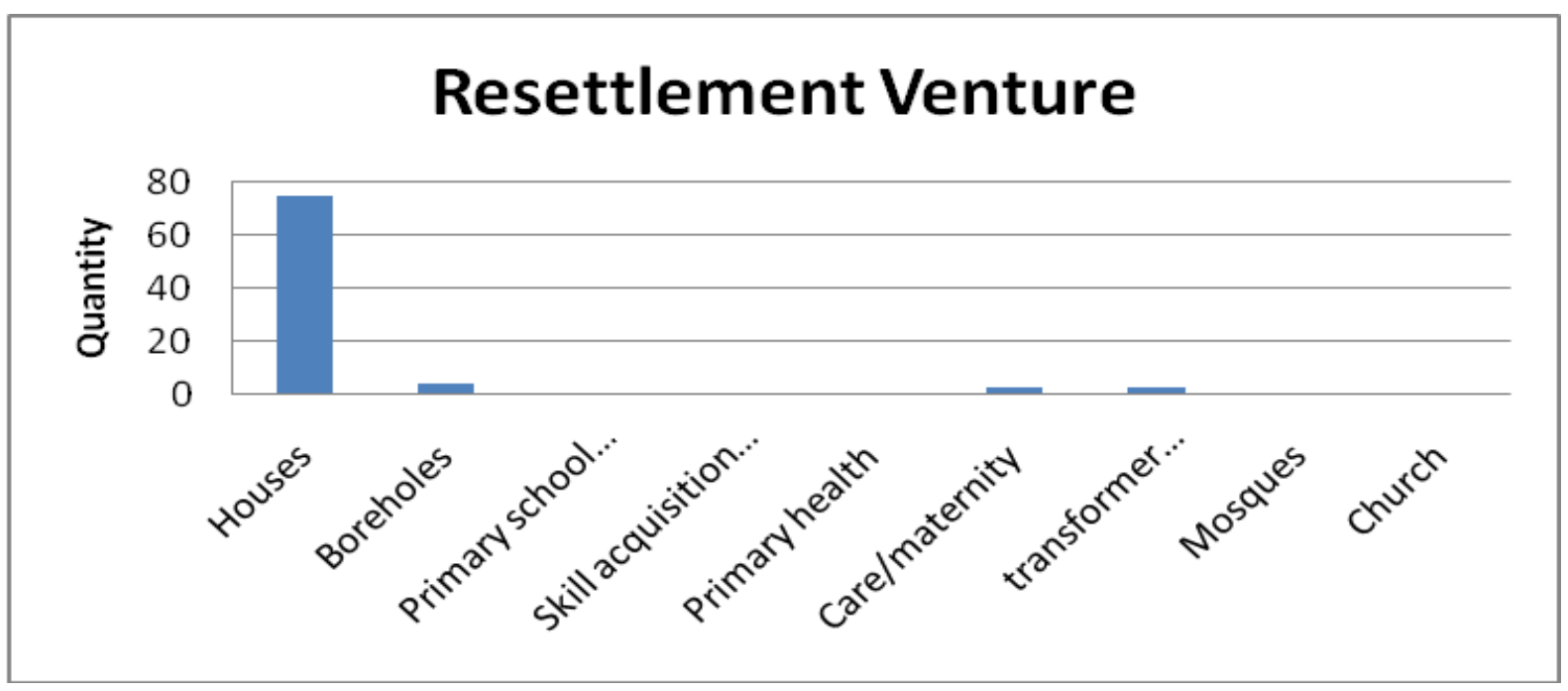

Figure 8: Graph showing resettlement programme in Maiganaga

Matthew, Mayeen, Yussof and Wan (2017) worked on samples of soil, coal and mine tailings from Maiganga coalfield (Nigeria coal) to obtain results of Mean activity concentrations of ${ }^{40} \mathrm{~K},{ }^{226} \mathrm{Ra}$ and ${ }^{232} \mathrm{Th}$ in coal, tailings and soil when assessed using HPGe $\gamma$-ray spectrometry (Gamma ray spectrometric technique).

Table 11: Assessment of Matthew, Mayeen, Yussof and Wan (2017)

\begin{tabular}{|l|l|l|l|}
\hline Samples & $\begin{array}{l}\text { Potassium, } \\
(\mathrm{Bq} / \mathrm{kg})\end{array}$ & $\begin{array}{l}{ }^{0} \mathrm{~K} \\
/ \mathrm{kg})\end{array}$ & $7.6 \pm 0.5$ \\
\hline In Coal & $17.8 \pm 1.2$ & 20 & $5.5 \pm 0.4$ \\
\hline World Mean Values( In Coal) & 50 & $20.2 \pm 1.0$ & 20 \\
\hline In Mine Tailings & $91.2 \pm 4.3$ & $17.7 \pm 0.9$ & $27.3 \pm 1.3$ \\
\hline In Soil & $83.5 \pm 4.0$ & 35 & 30 \\
\hline World Mean Values( In Soil) & 400 & ${ }^{226} \mathrm{Ra}(\mathrm{Bq}$ & \\
\hline
\end{tabular}

Table 12: Re-organizing the assessment of T. K., Mayeen U. K., Yusoff M. A. And Wan H. B.A. (2017)

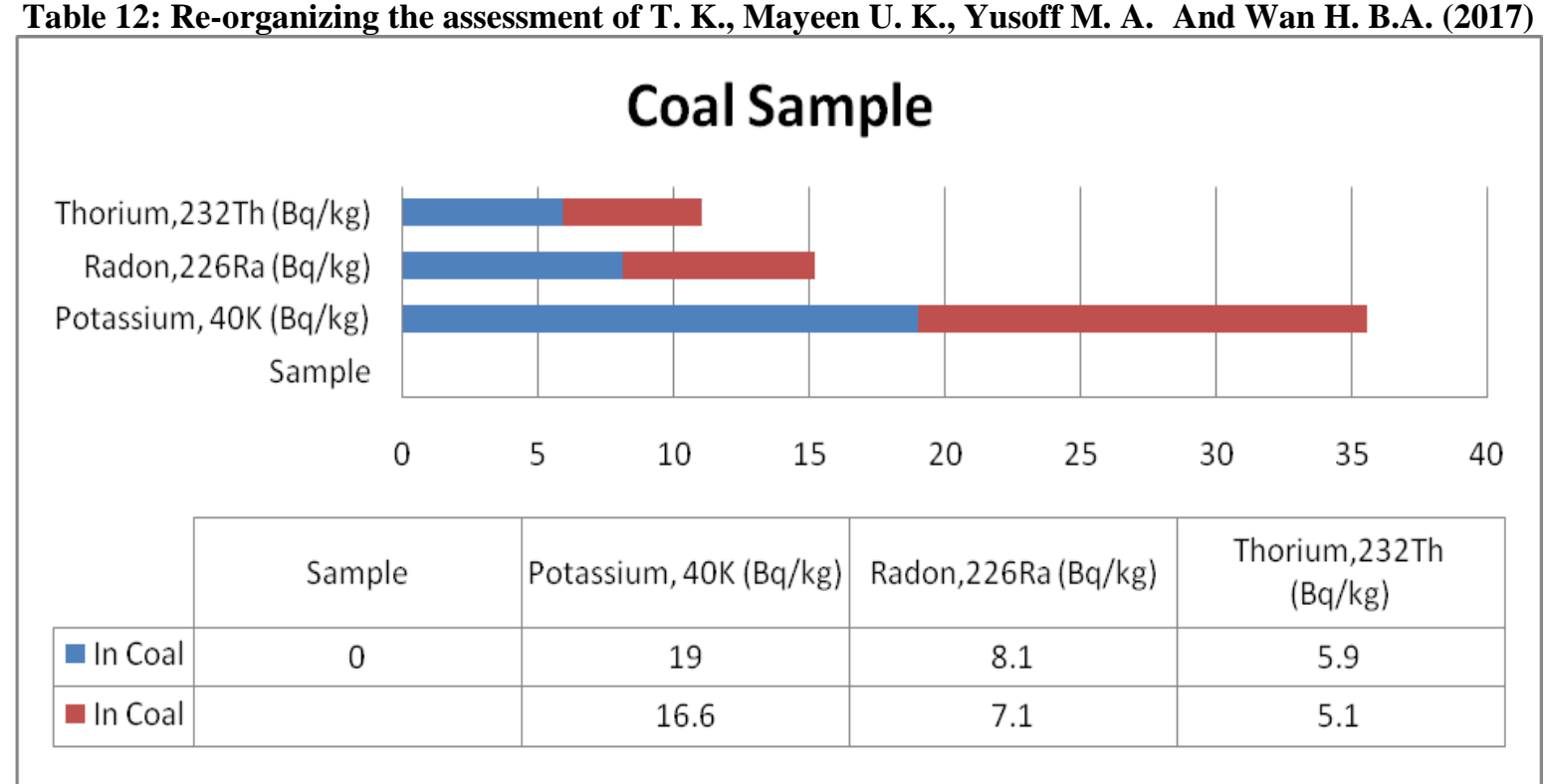

Figure 9: Metallic Concentrates In dust and in the soil 


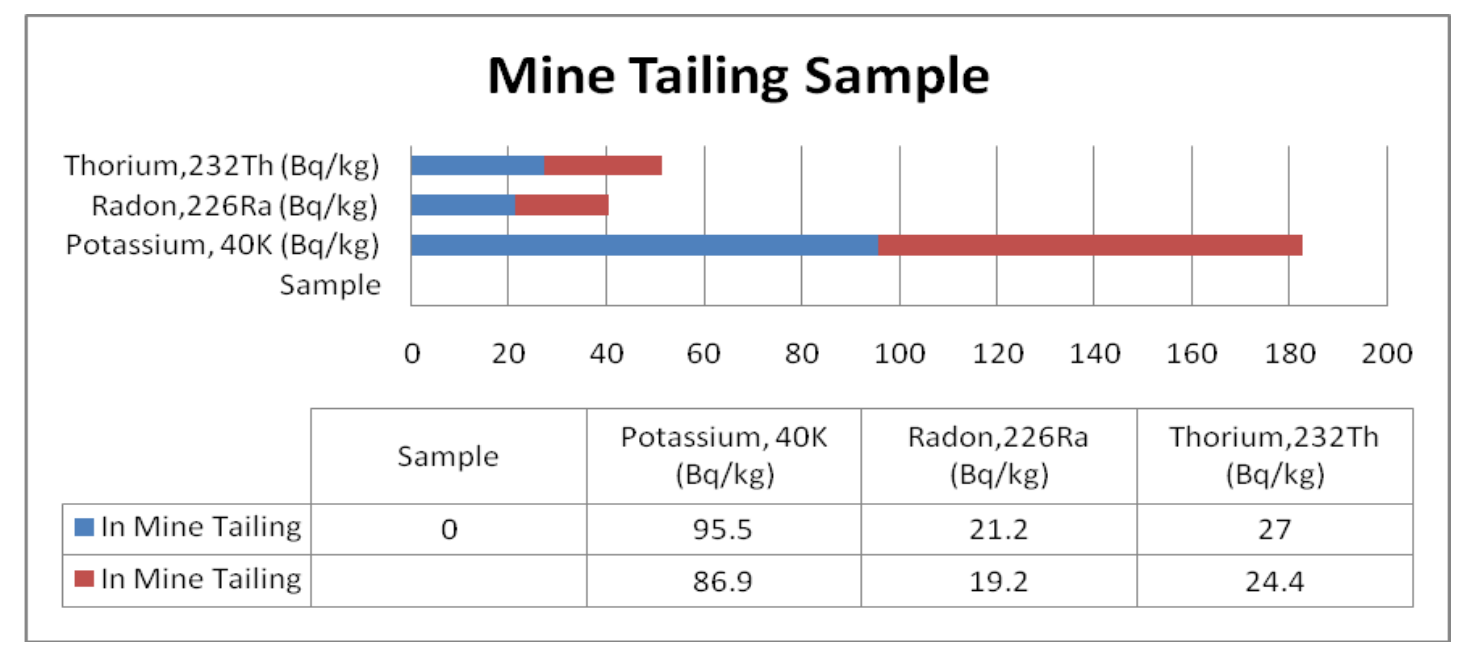

Figure 10: Metallic Concentrates In dust and in the soil

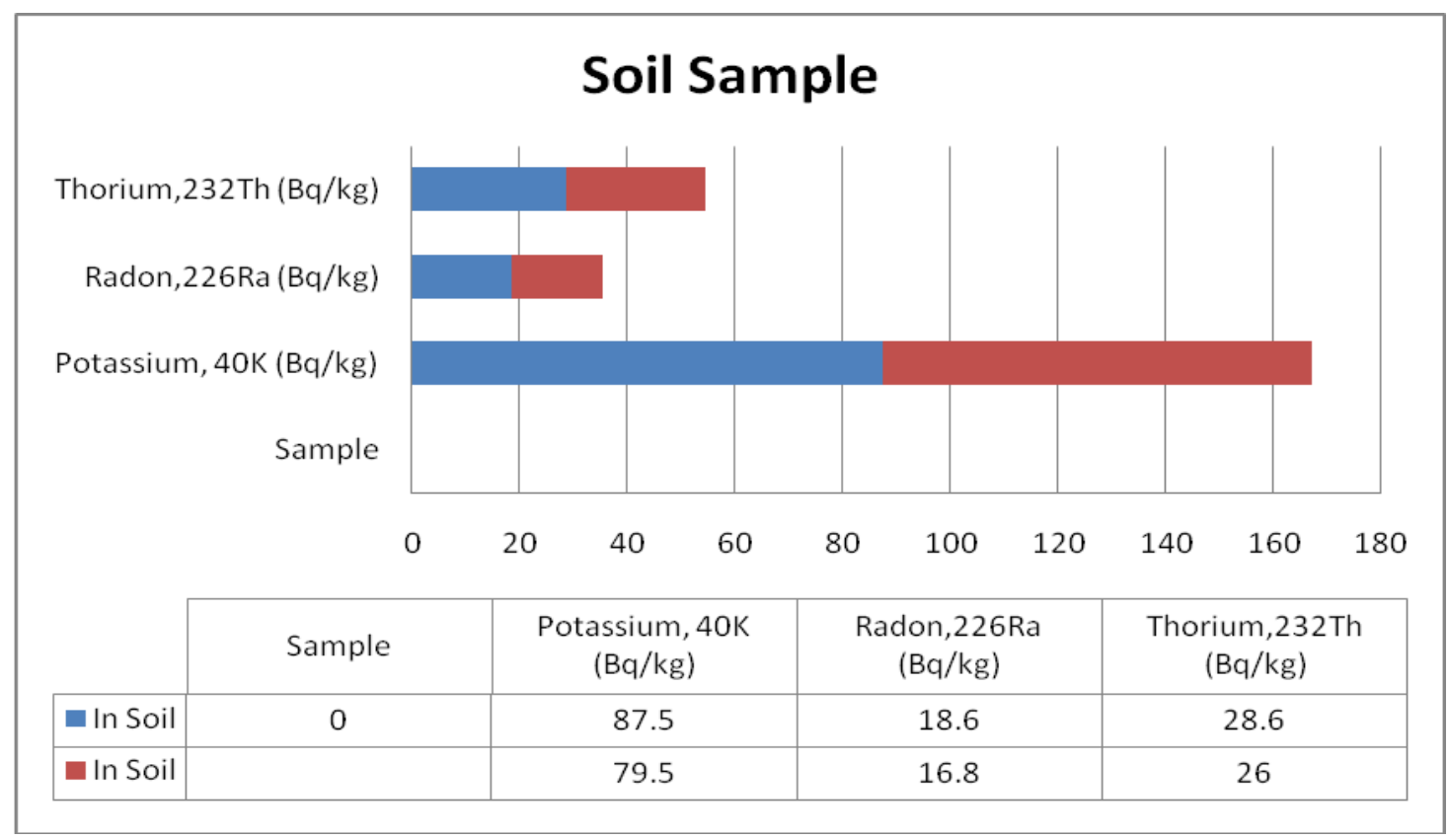

Figure 11: Metallic Concentrates In dust and in the soil

\section{RESULTS AND DISCUSSION}

In figure 4, though, Maiganga coal has a high beneficial coal content of about $61.69 \%$, it carries with it volatile matters of about $51.16 \%$. In figure 5 , the correlation coefficient for the graph showing radionuclide concentrations revealed Radon to be extremely high which may deduce the reason why Maiganga coal mine was abandoned. Same is confirmed in figure 9 to figure 11 which shows Thorium and Radon of high concentration, evidently present in the coal bed, coal tailings and in the soil of Maiganga coal mine.

In figure 6, samples collected from Maiganga mine drain, borehole and hand dug well vividly shows the extreme concentration of Nitrate as $155 \mathrm{mg} / \mathrm{l}, 75 \mathrm{mg} / \mathrm{l}$ and $143 \mathrm{mg} / \mathrm{l}$ respectively. This values are too far from the NESREA standard of 50mg/l.

A proposed solution to the challenge of Maiganga coal Mine is reclamation from its abandoned state. Although about $92 \%$ has been exploited by mining, leaving $8 \%$ (see table 8) not mined, vigorous reclamation should be adopted, earnestly; and the best method of reclamation to apply is the agricultural/forestry activities which involves planting species that were in the mine before operation was kickstarted (see table 9).

Other measures to help in giving a face-lift to Maiganga coal mine is the resettlement venture, as seen in table 10 , with provision of houses as top priority, as shown in figure 8.

\section{CONCLUSION AND RECOMMENDATION}

Mining activities generate and produce so much waste which is poisonous and destructive to aquatic animals, vegetation and man. These wastes include arsenic, lead, mercury, antimony, cyanide, cadmium, thorium, Radon. All these toxins affect health negatively during and after production. On Maiganga, Radon, thorium and Nitrate are in high concentration which is most likely reason for its abandonment. To resuscitate the land, reclamation and resettlement are suggested as best options.

Published By:

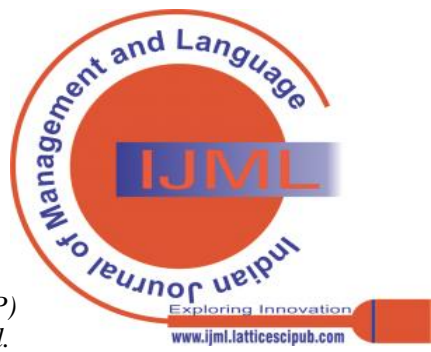




\section{REFERENCES}

1. Abaje I.B., Bello Y. and Ahmad S.A. (2020): A Review of Air Quality and Concentrations of Air Pollutants in Nigeria; J. Appl. Sci. Environ. Manage, Vol. 24 (2) 373-379. [CrossRef]

2. Abdulsalam M., Oruonye, E.D., Ahmed Y.M. and Mbaya L.(2016): An Assessment of the Socio-economic Impact of Maiganga Resettlement Scheme, Akko LGA, Gombe State, Nigeria; International Journal of Environmental \& Agriculture Research (IJOEAR), Vol 2, Issue-7, ISSN 2454-1850.

3. Adamu S.J, Mubarak B.G., Mahmoud A.B. (2014) Assessment of Some Heavy Metals Concentration in the Water of Maiganga Coa Mining Area Gombe - Nigeria, ResearchGate, Page 32 - 44.

4. Ademu T. O., Obaje D. O., Mohammed A. and Kumo L. (2020): Assessment of air quality within Maiganga coal mining area in Akko Local Government Area, Gombe State, Nigeria, Department of Chemistry, Nasarawa State University; World Journal of Biology Pharmacy and Health Sciences, 04(03), 001-012Babayo A. U., Santuraki[CrossRef]

5. A.H., Adebayo K.( 2018): An Assessment On Some Selected Heavy Metals In Soils Around Maiganga Coal Mine And Its Environs, Gombe State, Nigeria; Dutse Journal of Pure and Applied Sciences (DUJOPAS), Vol.4(1):456-465.

6. Chibuisi S.I.(2017): Environmental and Health Implications of Coal Mining at Maiganga, Gombe State, Nigeria; Department of Geology, Michael Okpara University of Agriculture, Umudike, Umuahia, Nigeria; Journal of Environment Pollution and Human Health, 2017, Vol. 5, No. 1, 5-14Denloye A. O. and Akinola A. A.( 2017): Utilising Clean Coal Technologies for Meeting Nigeria's Energy Needs, Journal of the Nigerian Society of Chemical Engineers, Chemical and Petroleum Engineering Department, University of Lagos, Lagos, Nigeria 32(2).

7. Dogan A.H., Bayram M. and Hazar T. (1999): The new approach to development project-induced resettlement in Turkey, International Journal of Water Resources Development, 15(3), 291-300. [CrossRef]

8. Kolo M.T., Amin Y.M., Khandaker M.U. and Abdullah W.H.B. ( 2017): Radionuclide Concentrations and Excess Lifetime Cancer Risk Due To Gamma Radioactivity In Tailing Enriched Soil around Maiganga Coal Mine, Northeast Nigeria; International Journal of Radiation Research, Volume 15, No 1.

9. Maina B., Kachalla A. and Comfort C.A. (2016): Impact of Coal Mining on the Environment in Maiganga Community of Akko Local Government, Gombe State, Nigeria; Global Journal of Human-Social Science, 16(3) 1-9.

10. Matthew et al, (2016): Quantification and Radiological Risk Estimation Due to the Presence of Natural Radionuclides in Maiganga Coal, Nigeria, PLos One, 11(6) [CrossRef]

11. Matthew T. K., Mayeen U. K., Yusoff M. A. and Wan H. B.A. (2017): Radiological Implications of Coal-Mining Activities in Maiganga Coalfield of North-Eastern Nigeria; Earth Systems and Environment volume 1, Article number: 14. [CrossRef]

12. NESREA (2011): 1st Eleven Gazetted Regulations Federal Republic of Nigeria Official Gazette.

13. Mining and Health (2012): A Community Guide to Environmental Health.

14. Nyakuma B. B. (2015): Physicochemical Characterization of Low Rank Nigerian Coals, arXiv, 1506.02068.

15. Obaje N.G. (2009): Geology and Mineral Resources, Lecture notes in Earth Science (London-Springe-Verlag Berlin Heidelberg, 57-76. [CrossRef]

16. Offodile M.E. (1976): A review of the Geology of The Cretaceous of The Benue Valley, in C.A Kogbe (ed.), Geology of Nigeria (Lagos:Elizathern Publishers).

17. Onoduku U.S. (2014): chemistry of Maiganga Coal Deposit, Upper Benue Trough, North Eastern Nigeria; Journal of Geoscience and Geomatics 2.3, 80-84.

18. Oruonye et al, (2016): Socioeconomic Impact of Artisanla and Small Scale Mining on the Mambilla Plateau of Taraba State, Nigeria; World Journal of Social Science Research 3(1): 2375 - 9747. [CrossRef]

19. Oruonye E. D., Iliya M. and Ahmed Y. M.( 2016): Sustainable Mining Practices in Nigeria: A Case Study of Maiganga Coal Mining in Gombe State; International Journal of Plant \& Soil Science 11(5): 1-9Priyambada P. and Dr. Sudhakar P. (2014): Impact of Iron Ore Mining on Human Health in Keonjhar District of Odisha, Ravenshaw University, Cuttack, India, Ravenshaw University, Cuttack, India; Volume 4, Issue 4, PP 23-2. [CrossRef]

20. Singh A.K., Mahato M.K., Neogi B., Mondal G.C. and Singh T.B., (2011): Hydro geochemistry, elemental flux and quality assessment of mine water in the Pootkee-Balihari mining area, Jharia coalfield, India, Mine water and the environment, 30(3), 197-207. [CrossRef]

21. Tawari C.C. and Abowei J. (2012): Air Pollution in the Niger Delta Area of Nigeria, Niger Delta University, Amassoma, Nigeria, Researchgate; A Review of Air Quality and Concentrations of Air Pollutants in Nigeria.

22. The Presidency, Federal Republic of Nigeria (2003): National energy policy.

23. Umar A. et al. (2020): Adsorption Study of Particle Sizes of Maiganga Coal, Centre for Energy Research and Training Ahmadu Bello University, Zaria, Nigeria; African Journal of Engineering and Environment Research Vol.1 (2) 2020 - ISSN: 2635-2974.

24. World Health Organization (2004): Guidelines for drinking water Geneva, Switzerland, WHO Library, Vol.1.

\section{AUTHOR PROFILE}

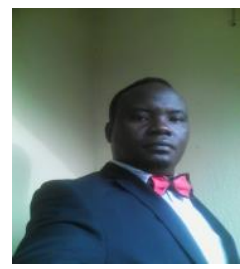

\section{Mining Engineer, Amosu Cyril Olumuyiwa} Professional background:

- $\quad$ Lecturer and researcher at Yaba College of Technology, Lagos, Nigeria.।

- Associate Environmental Professionals (AEP), National registry Of Environmental Professionals (NREP).

- Council for Regulation of Engineering in

Education: Nigeria (COREN)

- $\quad$ Master of Engineering (M. Eng.) in Mining Engineering from Federal University of Technology Akure, Nigeria (2019 - Date).

- Masters (M. Sc.) in Petroleum Engineering and Project Development (2004 - 2005).

- $\quad$ Bachelors of Engineering (B. Eng.) in Mining Engineering from Federal University of Technology Akure, Nigeria (1995 - 2001).

Previous publishing experience

About fifteen (15) journals and conference published already with different publishers which can be found on Google Scholar, ResearchGate, Publon and Orcid. These journals captures Mining and Petroleum.

Personal details:

Married with three (3) children; lives in Lagos state, Nigeria; Personal interest is writing and research.

Contact information:

Personal E-mail: muyixx1zillion@gmail.com

Official E-mail: Cyril.amosu@yabatech.edu.ng

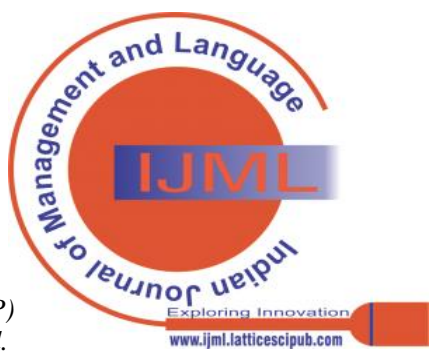

